\title{
Kompetensi Kepribadian dan Motivasi Mengajar Berpengaruh Terhadap Kinerja Guru PAUD
}

\section{Ni Komang Kartika1 ${ }^{*}$, Didith Pramunditya Ambara ${ }^{2}$}

1,2 Prodi Pendidikan Guru Pendidikan Anak Usia Dini, Universitas Pendidikan Ganesha, Singaraja, Indonesia

\section{ART I C LE I N F O}

\section{Article history:}

Received September 05, 2021

Revised September 10, 2021

Accepted October 22, 2021

Available online December 25, 2021

Kata Kunci:

Kepribadian, Motivasi Mengajar, Kinerja Guru

\section{Keywords:}

Personality, Teaching Motivation, Teacher Performance

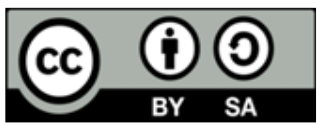

TThis is an open access article under the CC BY-SA license.

Copyright (C) 2021 by Author. Published by Universitas Pendidikan Ganesha.

\begin{abstract}
A B S T R A K
Masih rendahnya kompetensi kepribadian dan motivasi guru PAUD dalam mengajar terlihat dari guru yang masih cenderung mengedepankan pedagogik dan akademik daripada pengembangan kompetensi kepribadian dan terlihat guru yang masih sering datang terlambat serta kurangnya minat guru dalam membuat media pembelajaran yang baru dengan rancangan pembelajaran yang lebih menarik sehingga hal ini mempengaruhi kinerja guru. Oleh karena itu, penelitian ini bertujuan untuk menganalisis pengaruh dari kompetensi kepribadian dan motivasi mengajar terhadap kinerja guru PAUD. Penelitian ini merupakan jenis penelitian ex-post facto. Jumlah populasi dalam penelitian ini yaitu 103 guru dengan jumlah sampel sebanyak 82 orang. Metode pengumpulan data yang digunakan dalam penelitian ini yaitu dengan metode non tes berupa penyebaran kusioner. Instrumen yang digunakan menggunakan jenis kuisioner tertutup. Data penelitian yang diperoleh dianalisis menggunakan analisis statistik deskriptif dan analsis statistik inferensial dengan teknik analisis regresi linier sederhana dan analisis regresi linier berganda. Hasil penelitian menunjukan bahwa terdapat pengaruh yang signifikan antara kompetensi kepribadian dan motivasi mengajar terhadap kinerja guru (thitung 30,620 > tTabel 3,17). Sehingga, disimpulkan bahwa terdapat pengaruh yang signifikan kompetensi kepribadian dan motivasi mengajar terhadap kinerja guru PAUD. Implikasi dari penelitian ini yaitu hasil penelitian ini dapat digunakan sebagai refrensi terkait dengan hubungan antara kompetensi kepribadian dan motivasi mengajar guru PAUD terhadap kinerja guru.
\end{abstract}

\section{A BS TRACT}

The less of personality competence and motivation of PAUD teachers in teaching can be seen from the teachers who still tend to prioritize pedagogics and academics rather than the development of personality competencies, there are teachers still often arrive late, and the teacher's lack of interest in making new learning media with more interesting learning designs so it's affects teacher performance. So, this study aims to analiyze the effect of personality competence and teaching motivation on PAUD teacher performance. This research is an ex-post facto research type. The total population in this study were 103 teachers with a total sample of 82 people. The data collection method used in this study is the non-test method (questionnaires). The instrument used is a closed questionnaire. The research data obtained were analyzed with using descriptive statistical analysis and inferential statistical analysis with simple linear regression analysis techniques and multiple linear regression analysis. The results showed that there was a significant influence between personality competence and teaching motivation on teacher performance ( $t_{\text {count }} 30.620>t_{\text {table }} 3.17$ ). So, it's concluded that there is a significant influence of personality competence and teaching motivation on PAUD teacher performance. The implication of this research is that the results of this study can be used as a reference for the relationship between personality competence and teaching motivation of PAUD teachers on teacher performance.

\section{PENDAHULUAN}

Pendidikan anak usia dini dapat diartikan sebagai suatu upaya pembinaan yang memberikan stimulasi perkembangan dan pertumbuhan pada anak dalam rentang usia 0-6 tahun sebelum anak memasuki jenjang pendidikan dasar, sehingga anak memiliki kesiapan mental dan fisik dalam memasuki pendidikan lebih lanjut (Ayuni \& Setiawati, 2019; Tanu, 2017). Dengan adanya pendidikan untuk anak usia 
dini diharapkan dapat membantu mengembangkan aspek pertumbuhan dan perkembangan anak usia dini baik pertumbuhan dan perkembangan fisik, kecerdasan, sosial emosional, dan bahasa sesuai dengan tahap perkembangannya, sehingga pendidikan untuk anak usia dini sebaiknya mempunyai kualitas yang baik dalam mengembangkan pertumbuhan dan perkembangan anak (Botutihe, 2020; Mundia \& Setiawan, 2020). Kualitas dari pendidikan untuk anak usia dini dapat dilihat dari pengelolaan pendidikan, dimana salah satu bagian dari pengelolaan pendidikan adalah kinerja yang dimiliki oleh guru. Kinerja guru merupakan komponen yang saling berhubungan yang terdiri dari kemampuan yang harus dimiliki oleh seorang guru dalam menjalankan perannya sebagai pendidik dengan baik, dan dapat melaksanakan tugas yang diembannya secara secara profesional sesuai dengan kemampuan yang dimilikinya (Mahfud, 2021; Purwoko, 2018). Kinerja guru terlihat dari bagaimana sikap yang ditunjukan dalam sebuah kegiatan untuk mencapai tujuan dilaksanakan sebuah tugas yang sesuai dengan kriteria dan standar yang telah ditetapkan selama pelaksanaan pekerjaan tersebut (Janah et al., 2020; Pianda, 2018). Kinerja guru ialah suatu keberhasilan dalam melaksanakan kegiatan pembelajaran yang dilihat dari kemampuan guru dalam merencanakan, menerapkan dan menilai hasil belajar anak (Kartini \& Kristiawan, 2019; Lalupanda, 2019; Lie et al., 2019). Kinerja guru dikatakan baik jika guru memiliki loyalitas dan komitmen yang tinggi dalam mengajar, menguasai dan mengembangkan bahan pelajaran, disiplin dalam mengajar dan tugas-tugas lainnya, kreativitas dalam pelaksanaan pengajaran, kerjasama dengan semua warga sekolah, teladan bagi siswa, berkepribadian baik, jujur dan objektif dalam membimbing siswa, serta tanggung jawab untuk tugas mereka, dimana banyak faktor yang mempengaruhi kinerja guru antara lain kompetensi yang memadai dan wajar, kondisi kerja yang aman dan sehat, kesempatan untuk mengembangkan kemampuan, rasa memiliki, motivasi kerja, dan disiplin kerja (Kartini et al., 2020; Rahmayanti et al., 2021).

Namun, berdasarkan hasil observasi dan temuan yang didapatkan berdasarkan jurnal penelitian sebelumnya menyatakan bahwa kinerja guru di beberapa sekolah masih kurang dikarenakan kurang disiplinnya guru dalam mengajar. Hal ini didukung berdasarkan hasil penelitian yang menyatakan bahwa rendahnya kinerja guru di sekolah dipengaruhi oleh berbagai macam faktor diantaranya yaitu kompetensi, motivasi kerja, disiplin kerja, kepuasan kerja, organisasi tempat guru mengajar, kepemimpinan kepala sekolah, serta adanya kebijakan pemerintah tentang pendidikan (Abdullah, 2020). Hal ini selaras dengan hasil penelitian yang menyatakan bahwa kompetensi kepribadian guru pada sebagian guru masih kurang dilihat dari kenyataan pada pengembangan profesi guru masih cenderung mengedepankan pedagogik dan akademik daripada pengembangan kompetensi kepribadian dan terlihat guru yang masih sering datang terlambat, serta motivasi mengajar guru yang masih kurang dilihat dari kurangnya minat guru membuat media pembelajaran yang baru dan membuat rancangan pembelajaran yang lebih menarik serta bisa meningkatkan aspek-aspek perkembangan anak yang pada akhirnya berpengaruh terhadap kinerja guru (Agustin \& Nafiah, 2019; Anggraeni, 2017; Putri et al., 2019).

Hal ini tentunya tidak sejalan dengan konsep dari kinerja guru itu sendiri bahwa kinerja guru sebagai pelaksanaan tugas dan kewajiban sebagai pendidik merupakan salah satu faktor yang memegang peranan penting didalam keberhasilan pendidikan, dimana peran guru sangat dominan dalam membentuk siswa menjadi manusia yang berkualitas, tanpa mengurangi atau menghilangkan peran dan fungsi yang lain (Alhusaini et al., 2020; Septiani \& Cahyono, 2019; Suharsaputra, 2018). Kinerja guru menggambarkan kemampuan yang dimiliki guru dalam menjalan tugasnya sebagai tenaga pendidik. Kinerja guru merupakan salah satu faktor yang dapat mempengaruhi keberhasilan pendidikan di sekolah, maka dari itu setiap guru perlu meningkatkan skill yang dimiliki guna menunjang kinerjanya sebagai guru. Sehingga, untuk meningkatkan kinerja dari seorang guru perlu juga diperhatikan kompetensi kepribadian dan motivsi mengajar guru diluar faktor-faktor yang berpengaruh lainnya. Kompetensi kepribadian ialah kompetensi yang berkaitan dengan prilaku seorang guru dalam kehidupan sehari-hari yang mencerminkan kepribadian yang mantap, stabil, dewasa, arif, dan berwibawa, guru menjadi contoh bagi peserta didik, dan memiliki budi pekerti yang mulia, dimana kompetensi kepribadian merupakan faktor yang mempengaruhi kinerja guru untuk meningkatkan mutu pendidikan (Roqib \& Nurfuadi, 2020; Sofia \& Yulistia, 2020). Seorang guru hendaknya memiliki kepribadian yang mantap, stabil, dewasa, arif dan berakhlak mulia, serta diharapkan tumbuhnya kemandirian dalam menjalankan tugas dan terbiasa membangun etos kerja sehingga dapat memberikan pengaruh positif dalam kehidupan guru dalam menjalankan kegiatan kesehariannya (Arifai, 2018). Selain itu, motivasi mengajar juga perlu dimiliki oleh seorang guru selain kompetensi kepribadian untuk menunjang kinerja guru dalam proses pembelajaran. Guru mempunyai motivasi untuk melaksanakan kegiatan pembelajaran, sesuai dengan rancangan pembelajaran yang telah diatur. Motivasi mengajar guru merupakan faktor penting dalam meningkatkan kinerja guru dan pendorong kekuatan bagi guru dalam melakukan kegiatan mengajar secara totalitas sesuai ketentuan yang berlaku yang dapat dinilai dari prestasi kerja, pengukuran hasil kerja, peningkatan kerja kinerja, tanggung jawab, sifat pekerjaan, hubungan interpersonal, kemampuan kerja, kehidupan pribadi, kebijaksanaan dan administrasi, kesempatan untuk berkembang, pendapatan dan posisi (Normianti et al., 2019; Sofia \& Yulistia, 2020; 
Surani \& Mifthahudin, 2018). Motivasi guru yang tinggi sangat penting karena merupakan salah satu faktor yang memungkinkan mereka untuk secara efisien melaksanakan tugas pendidikan mereka, jika motivasi kerjanya tinggi maka akan berpengaruh tinggi terhadap kinerja dan sebaliknya jika motivasi rendah maka akan menyebabkan kinerja yang dimiliki juga rendah (Engin, 2020; Murkatik et al., 2020). Hal ini didukung oleh penelitian relevan yang menyatakan bahwa kinerja guru dipengaruhi oleh komptensi, motivasi mengajar dan lingkungan belajar (Alhusaini et al., 2020; Mulang, 2021). Dengan adanya motivasi yang tinggi maka guru akan terdorong untuk meningkatkan kemampuannya sehingga dapat merancang, melaksanakan dan mengevaluasi pembelajaran. Dengan demikian, kompetensi kepribadian dan motivasi mengajar memiliki pengaruh yang cukup signifikan terhadap kinerja guru. Maka dari itu peneliti tertarik untuk melakukan penelitian terkait dengan kompetensi kepribadian dan motivasi mengajar terhadap kinerja guru. Adapun penelitan ini bertujuan untuk menganalisis hubungan antara kompetensi kepribadian dan motivasi mengajar guru terhadap kinjera guru PAUD di TK Wilayah Kecamatan Blahbatuh.

\section{METODE}

Jenis penelitian yang digunakan dalam penelitian ini yakni penelitian kuantitatif dengan menggunakan rancangan ex post facto. Penelitian ini dilaksanakan di TK yang berada di wilayah Kecamatan Blahbatuh. Populasi dalam penelitian ini yaitu 103 guru. Dalam penelitian ini sampel diambil menggunakan teknik Proportional Random Sampling. Berdasarkan perhitungan dengan rumus slovin dengan tingkat presisi 5\% diperoleh jumlah sampel penelitian yaitu sebanyak 82 guru yang masing-masing tersebar di TK wilayah Kecamatan Blahbatuh. Adapun secara lebih rinci pembagian sampel penelitian disajikan pada Tabel 1.

Tabel 1. Sebaran Sampel Guru PAUD di Kecamatan Blahbatuh

\begin{tabular}{cllll}
\hline No & \multicolumn{1}{c}{ Desa/ Kelurahan } & Populasi & Sampel \\
\hline 1 & Bona & 8 & 7 & \\
2 & Belega & 4 & 3 & \\
3 & Kramas & 26 & 21 & \\
4 & Pering & 11 & 9 & \\
5 & Saba & 15 & 12 & \\
6 & Blahbatuh & 7 & 6 & \\
7 & Buruan & 14 & 11 & \\
8 & Bedulu & 18 & 14 & $\mathbf{8 2}$ \\
\hline
\end{tabular}

Pada pelaksanaan penelitian ini yang menjadi variable bebas yaitu kompetensi kepribadian dan motivasi mengajar sedangkan variabel terikatnya adalah kinerja guru PAUD. Metode pengumpulan data yang digunakan dalam penelitian ini yaitu metode non tes dengan menggunakan kuesioner/angket. Instrument yang digunakan dalam penelitian ini yakni menggunakan kuisioner dengan jenis kuisioner tertutup. Kuisioner yang disebarkan memuat tentang kompetensi kepribadian dan motivasi mengajar terhadap kinerja guru yang terdiri dari aspek kompetensi kepribadian, motivasi mengajar, dan kinerja guru. Jawaban pertanyaan dari setiap item instrumen menggunakan skala likert yang terdiri dari susunan tingkat dari sangat positif sampai sangat negative berupa kata sangat sesuai, sesuai, tidak sesuai, dan sangat tidak sesuai. Adapun kisi-kisi instrument penelitian disajikan secara berturut-turut pada Tabel 2, Tabel 3, dan Tabel 4.

Tabel 2. Kisi-kisi Aspek Kinerja Guru

\begin{tabular}{llll}
\hline No & Variabel & Dimensi & \\
\hline & Kinerja & Pedagogik & Menguasai karakteristik peserta didik. \\
& Guru & & Menguasai teori belajar dan prinsip-prinsip pembelajaran yang \\
& & mendidik. \\
1 & & Pengembangan kurikulum. \\
& & Kegiatan pembelajaran yang mendidik. \\
& & Pengembangan potensi peserta didik. \\
& & Komunikasi dengan peserta didik. \\
& & Penilain evaluasi. \\
& & Bertindak sesuai dengan norma agama, hukum, sosial dan \\
& & Sosial & \\
& &
\end{tabular}




\begin{tabular}{|c|c|c|c|}
\hline No & Variabel & Dimensi & Indikator \\
\hline & & & $\begin{array}{l}\text { Menunjukkan pribadi yang dewasa dan teladan. } \\
\text { Etos kerja, tanggung jawab yang tinggi, rasa bangga menjadi guru. } \\
\text { Bersikap inklusif, bertindak objektif, serta serta tidak deskriminatif. } \\
\text { Komunikasi dengan sesama guru, tenaga kependidikan, orang tua, } \\
\text { peserta didik, dan masyarakat. }\end{array}$ \\
\hline 3 & & Profesional & $\begin{array}{l}\text { Penguasaan materi, struktur, konsep dan pola pikir keilmuan yang } \\
\text { mendukung pembelajaran. } \\
\text { Mengembangkan keprofesian melalui tindakan reflektif. }\end{array}$ \\
\hline
\end{tabular}

Tabel 3. Kisi-kisi Aspek Kompetensi Kepribadian

\begin{tabular}{ll}
\hline \multicolumn{1}{c}{ Variabel } & \multicolumn{1}{c}{ Indikator } \\
\hline Kompetensi Kepribadian & Bertindak sesuai norma agama, hukum, sosial, dan budaya. \\
& Menampilkan diri sebagai pribadi yang jujur, berakhlak mulia dan \\
& teladan bagi masyarakat. \\
& Menampilkan diri sebagai pribadi yang mantap, stabil, dewasa, arif, \\
& dan wibawa. \\
& Menunjukkan etos kerja, tanggung jawab yang tinggi, rasa bangga \\
& menjadi guru, dan rasa percaya diri. \\
& Menjunjung tinggi kode etik guru. \\
\hline
\end{tabular}

Tabel 4. Kisi-kisi Aspek Motivasi Mengajar

\begin{tabular}{ll}
\hline Variabel & \multicolumn{1}{c}{ Indikator } \\
\hline & Tanggung jawab guru dalam menjalankan tugas. \\
& Menjalankan tugas dengan target yang jelas \\
& Memiliki tujuan yang jelas dan menantang. \\
& Ada umpan balik atas hasil pekerjaannya \\
& Memiliki perasaan senang dalam mengajar \\
& Selalu berusaha untuk mengungguli orang lain. \\
& Mengutamakan prestasi dari apa yang dikerjakannya. \\
Sotivasi Mengajar & kelalu berusaha memenuhi kebutuhan hidup dan kebutuhan \\
& Senang memperoleh pujian dari apa yang dikerjakan. \\
& Bekerja dengan harapan memperoleh insentif. \\
\hline
\end{tabular}

(Uno, 2017)

Untuk memastikan bahwa instrumen yang digunakan memiliki kualitas yang baik dan layak sebelum disebarkan kepada responden, maka instrumen ini harus di uji terlebih dahulu dengan melakukan uji kelayakan yang terdiri dari uji valitidas konstruk dan validitas butir yang kemudian dilanjutkan dengan uji reliabilitas. Jumlah ahli yang dilibatkan dalam pegujian kelayakan instrument berjumlah 2 orang sebagai ahli konstruk. Dari hasil pengujian instrumen yang dilakukan secara keseluruhan diperoleh hasil bahwa variabel kompetensi kepribadian, motivasi mengajar, dan kinerja guru dinyatakan reliabel dan layak untuk digunakan. Selanjutnya, setelah dilakukan penyebaran kuisioner data yang telah dikumpulkan di analisis menggunakan analisis statistik deskriptif dan analisis statistik inferensial. Teknik analisis statistik deskriptif dilakukan dengan central tendency yang meliputi skor data empiris yaitu skor minimum dan maksimum, perhitungan rerata (mean), skor tengah (median), modus (mode), standar deviasi (deviation standard) dan histogram tunggal, sedangkan untuk teknik analisis statistik inferensial menggunakan uji regresi linier sederhana dan uji regresi linier ganda dengan uji prasyarat analisis yang terdiri dari uji normalitas dengan menggunakan rumus Kolmogorov-Smirnov, uji linieritas, uji multikolinieritas dan uji heterokedastisitas.

\section{HASIL DAN PEMBAHASAN}

Hasil

Data yang diperoleh dari hasil penelitian ini adalah data hasil sebaran kuisioner kinerja guru, kompetensi kepribadian, dan motivasi mengajar guru PAUD di wilayah Kecamatan Blahbatuh. Berdasarkan hasil analisis deskriptif skor rata-rata kinerja guru sebesar 87,93 dikonversikan ke dalam pedoman Penilaian Skala Lima tergolong kategori tinggi, untuk skor rata-rata kompetensi kepribadian sebesar 87,80 
dikonversikan kedalam pedoman Penilaian Skala Lima tergolong kategori tinggi, dan skor rata-rata motivasi mengajar sebesar 87,73 dikonversikan kedalam pedoman Penilaian Skala Lima tergolong kategori tinggi. Sebelum dilakukan pengujian hipotesis dengan menggunakan analisis regresi, data yang diperoleh terlebih dahulu dilakukan uji prasyarat yang terdiri dari uji normalitas, uji linieritas, uji multikolinieritas dan uji heterokedastisitas. Uji normalitas pada penelitian ini dilakukan dengan menggunakan rumus Kolmogorov-Smirnov dengan ketentuan apabila nilai maksimum $\leq$ nilai Tabel Kolmogorov-Smirnov, maka data berdistribusi normal, sebaliknya jika nilai maksimum > nilai Tabel Kolmogorov-Smirnov, maka data tidak berdistribusi normal. Berdasarkan hasil uji normalitas sebaran data, variabel kompetensi kepribadian, motivasi mengajar, dan kinerja guru berdistribusi normal. Selanjutnya dilakukan Uji liniertitas data.

Uji linieritas bertujuan untuk mengetahui apakah variabel bebas dengan variabel terikat mempunyai hubungan linier atau tidak. Pada penelitian ini uji linieritas menggunakan uji F dengan kriteria yang diterapkan untuk menyatakan kelinieran adalah nilai signikansi F yang diperoleh lebih besar dari 0,05. Berdasarkan hasil uji linieritas diperoleh hasil bahwa $\mathrm{X}_{1}$ dengan Y memperoleh hasil $\mathrm{F}_{\text {hitung }}$ sebesar 1,160 dengan signifikansi sebesar 0,316 sehingga dinyatakan linier, sedangkan untuk hasil uji linieritas $\mathrm{X}_{2}$ dengan Y memperoleh hasil $F_{\text {hitung }}$ sebesar 1,407 dengan signifikansi sebesar 0,149 sehingga dinyatakan linier. Dari data tersebut maka dapat disimpulkan bahwa hubungan antara kompetensi kepribadian dengan kinerja guru dan motivasi mengajar dengan kinerja guru adalah linier. Kemudian uji prasyarat dilanjutkan dengan uji Multikolinieritas. Uji multikolinieritas pada penelitian ini dilakukan dengan matriks korelasi. Pengujian ini bertujuan untuk mengetahui ada tidaknya gejala multikolinieritas yang dilakukan dengan memperhatikan nilai matriks korelasi yang dihasilkan pada saat pengelolaan data serta nilai VIF berada dibawah 10 dan nilai toleransi lebih dari 0,10 dengan kesimpulan bahwa model regresi tersebut tidak terdapat problem multikolinieritas. Berdasarkan hasil uji multikolinieritas diperoleh hasil kompetensi kepribadian dengan tolerance 0,778 dan nilai VIP sebesar 1,285 sehingga dinyatakan tidak terjadi masalah multikolinieritas, sedangkan motivasi mengajar dengan tolerance 0,778 dan nilai VIP sebesar 1,285 sehingga dinyatakan tidak juga terjadi masalah multikolinieritas. Sehingga, dapat disimpulkan bahwa tidak terjadi masalah multikolinieritas baik pada variabel kompetensi kepribadian ataupun motivasi mengajar. Selanjutnya dilakukan uji Heterokedastisitas. Uji heterokedastisitas digunakan untuk melihat apakah terdapat ketidaksamaan varian dari residual satu ke pengamat yang lain. Prasyarat yang harus terpenuhi dalam model regresi ini adalah tidak adanya gejala heterokedastisitas. Heteroskedastisitas pada penelitian ini di uji dengan uji glejser dengan meregresikan nilai residul dengan masing-masing variabel. Pengujian heteroskedastisitas dilakukan dengan berbantuan SPSS 21.0 for windows. Hasil uji heterokedastisitas disajikan pada gambar 1 .

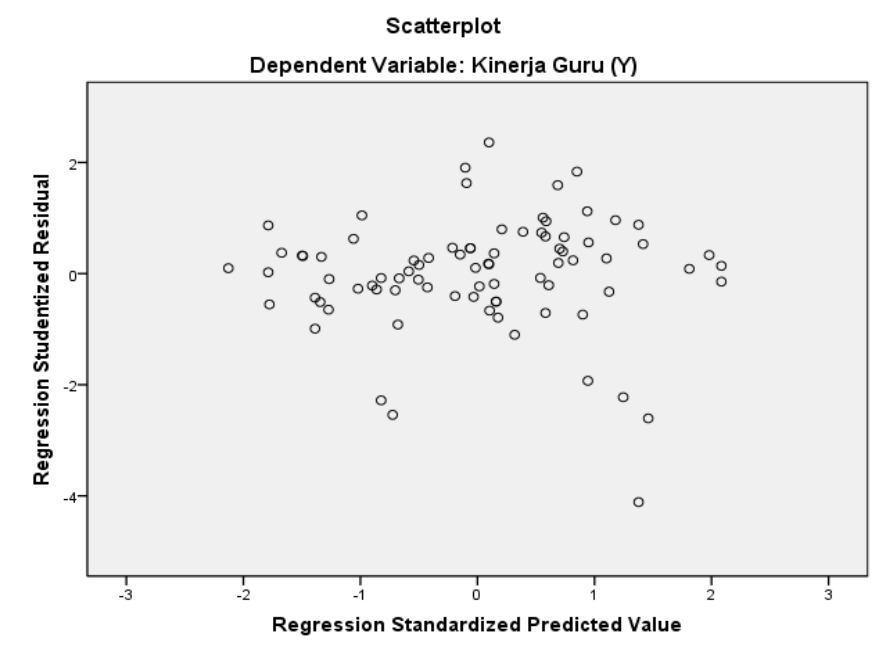

Gambar 1. Uji Heterokedastisitas Data

Berdasarkan gambar 01 terlihat bahwa tidak ada pola yang jelas serta titik-titik yang menyebar di atas dan di bawah angka nol pada sumbu Y, sehingga dapat disimpulkan tidak terjadi Heterokedastisitas. Setelah dilakukan uji prasyarat dan semua uji prasyarat sudah terpenuhi, maka dilanjutkan pada pengujian hipotesis. Pengujian hipotesis dalam penelitian ini menggunakan regresi berganda dimana akan diuji secara empirik untuk mencari hubungan fungsional dua atau lebih variabel bebas dengan variabel terikat, atau untuk meramalkan dua variabel bebas atau lebih terhadap variabel terikat. Konstanta sebesar -4,693, koefisien regresi $\mathrm{X}_{1}$ sebesar 0.797, dan koefisien regresi $\mathrm{X}_{2}$ sebesar 0,254. Selanjutnya dilakukan analisis determinasi. Koefisien determinasi (R2) mengukur seberapa jauh kemampuan model dalam menerangkan 
variasi variabel kinerja guru. Berdasarkan hasil analisis, dapat diketahui bahwa angka koefisien korelasi (R) sebesar 0,877. Dari angka tersebut dapat diambil kesimpulan bahwa hubungan antara variabel independen dengan variabel dependen sangat kuat. Besarnya R Square (R2) adalah 0,768. Hasil perhitungan statistik ini berarti bahwa kemampuan variabel independen (kompetensi kepribadian dan motivasi mengajar) dalam menerangkan variasinya perubahan variabel dependen (kinerja guru) sebesar $76,8 \%$, sedangkan sisanya sebesar 23,2\% (100\% - 76,8\%) diterangkan oleh faktor-faktor lain di luar model regresi yang dianalisis.

Pengujian hipotesis I, II, III dalam penelitian ini dibantu menggunakan SPSS 21.0 for windows. Pengujian hipotesis I dan II menggunakan uji regresi linier sederhana dan pengujian hipotesis III menggunakan uji regresi linier berganda. Dalam variabel $\mathrm{Rx} 1 \mathrm{y} \mathrm{t}_{\text {hitung }}=12,519$. Karena $\mathrm{t}_{\text {hitung }}>\mathrm{t}_{\text {Tabel }}(12,519$ $>1,96$ ) maka dapat disimpulkan bahwa $\mathrm{H}_{1}$ diterima dan $\mathrm{H}_{0}$ ditolak. Artinya ada pengaruh signifikan kompetensi kepribadian ( $\mathrm{X}_{1}$ ) terhadap kinerja guru (Y). Selanjutnta dalam variabel Rx2y thitung $=3,164$. Karena $t_{\text {hitung }}>\mathrm{t}_{\text {Tabel }}(3,164>1,96)$ maka dapat disimpulkan bahwa $\mathrm{H}_{1}$ diterima dan $\mathrm{H}_{0}$ ditolak. Artinya ada pengaruh signifikan motivasi mengajar $\left(\mathrm{X}_{1}\right)$ terhadap kinerja guru $(\mathrm{Y})$. Kemudian untuk variabel $\mathrm{Rx} 1 \mathrm{x} 2 \mathrm{y}$ $t_{\text {hitung }}=30,620$. Karena thitung $>t_{\text {Tabel }}(30,620>3,17)$ maka dapat disimpulkan bahwa $\mathrm{H}_{1}$ diterima dan $\mathrm{H}_{0}$ ditolak artinya kompetensi kepribadian $\left(\mathrm{X}_{1}\right)$ dan motivasi mengajar $\left(\mathrm{X}_{2}\right)$ secara simultan berpengaruh terhadap kinerja guru (Y). Dari hasil perhitungan yang diperoleh dapat diketahui bahwa kinerja guru PAUD dapat dipengaruhi oleh faktor kompetensi kepribadian dan juga motivasi mengajar guru. Semakin tinggi kompetensi kepribadian dan motivsi mengajar guru makan akan semakin tinggi pula kinerja guru, dan sebaliknya jika kompetensi kepribadian dan motivsi mengajar guru kurang makan akan berkurang juga kinerja guru.

\section{Pembahasan}

Penelitian yang dilaksanakan di TK wilayah Kecamatan Blahbatuh dengan jumlah responden sebanyak 82 guru, bertujuan untuk mengetahui pengaruh kompetensi kepribadian dan motivasi mengajar terhadap kinerja guru dalam pelaksanaan pembelajaran di PAUD. Kompetensi kepribadian merupakan kemampuan personal guru yang mencerminkan kepribadian yang dewasa, stabil, berakhlak mulia dan dapat dijadikan teladan oleh siswa atau dengan kata lain menjadi guru yang memiliki etika untuk siswasiswanya serta di sisi lain untuk menampakkan sikap positif bagi siswa (Pratiwi et al., 2021; Zola \& Mudjiran, 2020). Guru harus bisa menjaga wibawa didepan peserta didiknya karena guru adalah sosok yang selalu dijadikan teladan dan panutan siswanya. Dengan adanya peningkatan kompetensi tentunya akan berpengaruh terhadap kinerja guru. Kompetensi mempunyai pengaruh yang signifikan terhadap kinerja guru, dimana guru yang kompeten akan menyelesaikan tanggung jawabnya dengan benar, mengerahkan segenap hati dan pikiran untuk menghantarkan siswa menjadi berprestasi, mandiri, dan berakhlak mulia sehingga dengan adanya kompetensi guru mampu bekerja atau melaksanakan tugasnya dalam proses pembelajaran agar bisa menghasilkan kinerja yang baik dalam menjalankan profesinya sebagai guru (Baharudin, 2017; Heriswanto, 2018; Royani et al., 2020). Hasil penelitian ini didukung oleh hasil penelitian sebelumnya yang menyatakan bahwa adanya pengaruh signifikan kompetensi kepribadian terhadap kinerja guru (Putri et al., 2019; Sopandi, 2019). Maka dari itu kompetensi kepribadian merupakan hal yang sangat penting yang harus dikembangkan oleh guru. Kompetensi kepribadian guru yang tinggi akan memberikan dorongan kuat bagi guru tersebut bekerja dengan baik sehingga menghasilkan kinerja yang maksimal sedangkan kompetensi kepribadian guru yang rendah menyebabkan guru kurang antusias dalam bekerja sehingga hasil kerja yang dicapai kurang masksimal.

Selain itu, hasil analisis mengenai hubungan antara motivasi mengajar ada pengaruh signifikan motivasi mengajar $\left(\mathrm{X}_{2}\right)$ terhadap kinerja guru $(\mathrm{Y})$. Motivasi dalam mengajar sering dikaitkan dengan motivasi kerja. Motivasi kerja dalam hal ini seorang guru memiliki dorongan dalam dirinya untuk mencapai kepuasan bekerja atau mengajar. Motivasi mengajar merupakan dorongan kerja yang timbul dalam diri pribadi yang membuat seorang guru mempunyai keinginan yang menyebabkan munculnya level, arah dalam mencapai tujuan yang ditetapkan dalam pembelajaran melalui pelaksanaan tugas, sehingga guru dapat menjalankan tugasnya dan dapat dilaksanakan dengan baik sehingga bisa mencapai cita-cita yang diharapkan (Y. Hidayat, 2020; Setiawan, 2020; Sulfemi, 2020). Sehingga, dapat disimpulkan bahwa motivasi dalam mengajar merupakan suatu dorongan yang ada dalam diri untuk mencapai tujuan yang diinginkan sehingga bisa menjalankan tugasnya dan mampu menyesuaikan diri dengan lingkungan kerja sehingga mampu mencapai tujuan yang telah ditetapkan. Motivasi kerja sangat membantu guru dalam melakukan aktivitas sehari-hari, maka dari itu motivasi kerja diartikan sebagai salah satu faktor yang ada dalam diri seorang guru yang mampu memberikan semangat kerja untuk bisa mencapai tujuan yang telah ditetapkan sehingga tanpa adanya motivasi kerja tentu menyebabkan kinerja guru tidak dapat berjalan dengan baik sesuai dengan yang diharapkannya (Arlita et al., 2020; Kristiawan \& Rahmat, 2018). Hal ini didukung oleh hasil penelitian sebelumnya yang menyatakan bahwa adanya pengaruh yang signifikan motivasi kerja 
terhadap kinerja guru (Haingu, 2019; Nurdin, 2017). Maka dari itu, jika guru memiliki motivasi yang tinggi dalam melaksanakan pembelajaran yang menyebabkan adanya peningkatkan kinerja guru sehingga akan berpengaruh terhadap pelaksanaan pembelajaran serta tentunya akan berpengaruh juga terhadap hasil belajar siswa.

Hasil uji hipotesis pengaruh kompetensi kepribadian dan motivasi mengajar terhadap kinerja guru juga menunjukkan secara simultan berpengaruh terhadap kinerja guru (Y). Hal ini berarti bahwa baik buruknya kinerja guru dipengaruhi oleh kompetensi kepribadian dan juga motivasi mengajar guru. Kompetensi kepribadian guru sudah seharusnya melekat dalam pribadi seorang guru, sehingga dapat merefleksi kegiatan pembelajarannya di kelas, sejauh mana prestasi yang diperoleh, tanggung jawab, mandiri, dan seberapa besar dapat mengendalikan emosi agar kompetensi kepribadian guru dapat memberikan pengaruh positif terhadap motivasi mengajar guru, dimana meningkatkan motivasi dapat melalui dorongan secara eksternal dan internal yang nantinya hal ini akan berdampak terhadap kinjera guru (Dewi et al., 2018; Sofia \& Yulistia, 2020). Maka dari itu, seiring dengan peningkatan kompetensi guru, perlu diimbangi adanya motivasi tinggi dalam mengajar dimana motivasi dalam mengajar ini akan memunculkan dorongan, kesadaran dan gairah dalam mengajar sehingga guru akan termotivasi untuk mengembangkan diri dan meningkatkan kompetensinya guna menunjang efektifitas pembelajaran sehingga menghasilkan kinerja yang baik (Sopandi, 2019; Surani \& Mifthahudin, 2018). Hal ini didukung oleh hasil penelitian terdahulu yang menyatakan bahwa kompetensi guru dan motivasi mengajar memberikan pengaruh terhadap kinerja guru (Giantoro \& Haryadi, 2019; Yunanda, 2019). Maka dari itu, untuk menghasilkan kinerja yang baik guru harus dapat mengembangkan kompetensinya salah satunya kompetensi kepribadian yang dibarengin dengan tumbuhnya motivasi mengajar yang tinggi,

Berdasarkan pemaparan tersebut, dapat diketahui bahwa kompetensi kepribadian dan motivasi mengajar berpengaruh terhadap kinerja guru di TK Kecamatan Blahbatuh, sehingga guru-guru di TK Kecamatan Blahbatuh perlu memaksimalkan dan mengembangkan kompetensi kepribadian dan motivasi mengajar mereka agar mencapai kinerja guru yang baik dan nantinya dapat memberikan feedback yang baik dalam pelaksanaan pembelajaran di kelas. Kompetensi guru dan juga motivasi mengajar hendaknya dapat dilaksanakan dan dikembangkan dengan baik, dikarenakan semakin meningkatnya kompetensi kepribadian dan motivasi mengajar maka kinerja guru juga akan meningkat dan begitu juga sebaliknya semakin kurangnya kompetensi kepribadian dan motivasi mengajar yang dimiliki oleh guru maka akan berpengaruh terhadap kurangnya kinerja guru (Anggraini et al., 2021; Yunanda, 2019). Hal ini didukung oleh hasil penelitian terdahulu yang menyatakan bahwa bahwa kompetensi dan motivasi berpengaruh secara simultan maupun parsial terhadap kinerja guru, secara parsial motivasi lebih berpengaruh terhadap kinerja guru, tetapi tingkat kompetensi yang dimiliki seorang guru juga akan berpengaruh terhadap tinggi rendahnya kinerja seorang guru (A. Hidayat, 2021; Rasam et al., 2019). Penelitian lainnya juga menyatakan bahhwa semakin baik kompetensi seseorang dengan motivasi tinggi disertai dengan lingkungan belajar yang baik maka secara langsung mempengaruhi kinerja guru, dimana guru dengan kinerja yang baik akan dapat menumbuhkan semangat dan motivasi belajar siswa menjadi lebih baik dan pada akhirnya akan mampu meningkatkan kualitas pembelajaran termasuk secara tidak langsung memberikan kontribusi terhadap mutu pendidikan (Aditya et al., 2020; Mulang, 2021). Kontribusi dari adanya penelitian ini yaitu dapat digunakan sebagai acuan atau tolak ukur terkait kompetensi kepribadian dan motivasi mengajar guru yang memiliki pengaruh terhadap kinerja guru, sehingga dengan adanya penelitian ini dapat digunakan sebagai refrensi dalam mengkaji faktor-faktor yang mempengaruhi kinjera guru. Selain itu, penelitian ini memiliki kelebihan jika dibandingkan dengan penelitian lainnya, dimana karena masih minimnya penelitian yang mengkaji tentang komptensi kepribadian dan motivasi mengajar terhadap kinerja guru, maka hasil penelitian ini dapat digunakan sebagai bahan kajian atau tambahan refrensi terkait faktor-faktor yang mempengaruhi kinerja guru.

Temuan-temuan yang didapatkan dari penelitian ini memberikan implikasi bahwa kompetensi kepribadian dan motivasi mengajar berpengaruh terhadap kinerja guru, sehingga hasil penelitian ini dapat dijadikan sebagai refrensi ataupun bahan kajian untuk pengembangan penelitian yang berkaitan dengan korelasi antara kompetensi kepribadian dan motivasi mengajar terhadap kinerja guru. Selain itu, karena keterbatasan penelitian ini yang hanya mengkaji pengaruh kompetensi kepribadian dan motivasi mengajar terhadap kinerja guru, penulis merekomendasikan agar penelitian selanjutnya dapat mengkaji atau memperluas variabel penelitian yang hendak dikaji.

\section{SIMPULAN}

Pada pelaksanaan pembelajaran kompetensi kerpibadian dan motivasi mengajar guru dapat mempengaruhi kinerja dari seorang guru. Hal ini dapat dilihat dari hasil penelitian yang dilakukan di TK wilayah Kecamatan Blahbatuh bahwa kompetensi kepribadian guru mempengaruhi kinerja guru PAUD, 
selain itu motivasi mengajar juga berpengaruh terhadap kinerja guru PAUD. Maka dari itu, untuk meningkatkan kinerja dari guru diperlukan kompetensi kepribadian dan motivasi mengajar guru yang tinggi.

\section{DAFTAR RUJUKAN}

Abdullah, A. (2020). Relationship the Work Culture and Training Programs Within Performance. International Journal of Progressive Sciences and Technologies (IJPSAT), 20(1), 92-101. https://doi.org/10.52155/ijpsat.v20.1.1727.

Aditya, A. M., Setyadi, A. R., \& Leonardho, R. (2020). Analisis Strategi Guru dalam Meningkatkan Motivasi Belajar Siswa. Manazhim, 2(1), 97-104. https://doi.org/10.36088/manazhim.v2i1.668.

Agustin, I. T., \& Nafiah. (2019). Pengaruh Kompetensi Kepribadian Guru terhadap Pembentukan Karakter Siswa di SD Negeri Margorejo VI/524 Surabaya. Education and Human Development Journal, 4(2), 2132. https://doi.org/10.33086/ehdj.v4i2.1122.

Alhusaini, A., Kristiawan, M., \& Eddy, S. (2020). Pengaruh Motivasi Kerja Dan Disiplin Kerja Terhadap Kinerja Karyawan. Jurnal Pendidikan Tambusai, 4(3), 2166-2172. https://doi.org/10.31004/jptam.v4i3.693.

Anggraeni, A. D. (2017). Kompetensi Kepribadian Guru Membentuk Kemandirian Anak Usia Dini (Studi Kasus di TK Mutiara, Tapos Depok). AWLADY: Jurnal Pendidikan Anak, 3(2), 28-47. https://doi.org/10.24235/awlady.v3i2.1529.

Anggraini, W. R., Hartati, C. S., \& Utari, W. (2021). Pengaruh Kompetensi Kepribadian dan Kecerdasan Emosional Terhadap Kinerja Guru SMP Negeri 13 Balikpapan. Jurnal Manajerial Bisnis, 4(3), 257-268. https://doi.org/10.37504/mb.v4i3.343.

Arifai, A. (2018). Kompetensi Kepribadian Guru Dalam Perspektif Pendidikan Islam. Raudhah Proud To Be Professionals : Jurnal Tarbiyah Islamiyah, 3(1), 27-38. https://doi.org/10.48094/raudhah.v3i1.21.

Arlita, S. E., Ahyani, N., \& Missriani, M. (2020). Pengaruh Kompetensi Akademik dan Motivasi Guru Terhadap Kinerja Guru. Attractive : Innovative Education Journal, 2(3), 8. https://doi.org/10.51278/aj.v2i3.70.

Ayuni, D., \& Setiawati, F. A. (2019). Kebun Buah Learning Media for Early Childhood Counting Ability. Jurnal Obsesi : Jurnal Pendidikan Anak Usia Dini, 3(1), 1-9. https://doi.org/10.31004/obsesi.v3i1.128.

Baharudin, H. (2017). Peningkatan Kompetensi Guru Melalui Sistem kepemimpinan Kepala Madrasah. Jurnal Ilmu Tarbiyah At-Tajdid, 6(1), http://ejournal.inismupacitan.ac.id/index.php/tajdid/article/view/38.

Botutihe, S. N. (2020). Pola Pengelolaan Pendidikan Anak Usia Dini di Kota Gorontalo. Jurnal Obsesi : Jurnal Pendidikan Anak Usia Dini, 4(2), 883-891. https://doi.org/10.31004/obsesi.v4i2.481.

Dewi, R. S., Kurniaitun, T. C., \& Abubakar. (2018). Kemampuan Profesional Guru Dan Motivasi Kerja Terhadap Kinerja Mengajar Guru Sekolah Dasar. Jurnal Administrasi Pendidikan, 25(1), 150-158. https://doi.org/10.17509/jap.v25i1.11581.

Engin, G. (2020). An Examination of Primary School Students' Academic Achievements and Motivation In Terms of Parents' Attitudes, Teacher Motivation, Teacher Self-efficacy and Leadership Approach. International Journal of Progressive Education, 16(1), 2020. https://doi.org/10.29329/ijpe.2020.228.18.

Giantoro, H. M., \& Haryadi, R. P. (2019). Pengaruh Kompetensi Guru , Kepemimpinan Kepala Sekolah Menurut Persepsi Guru dan Motivasi Kerja Terhadap Kinerja Guru SMK Negeri di Kabupaten Purbalingga. Jurnal Ekonomi, Bisnis, Dan Akuntansi (JEBA), 21(2), 1-11. https://doi.org/10.32424/jeba.v21i2.1290.

Haingu, R. M. (2019). Pengaruh Motivasi Kerja Terhadap Kinerja Guru Paud di Kecamatan Kota Tambolaka dan Loura Kabupaten Sumba Barat Daya. Jurnal Edukasi Sumba (JES), 3(2), 61-65. https://doi.org/ 10.53395/jes.v3i2.57.

Heriswanto, H. (2018). Pengaruh Kompetensi Guru Terhadap Kinerja Guru SMPN I Lambuya Kab. Konawe Melalui Motivasi Kerja Sebagai Variabel Intervening. Jurnal Akrab Juara, 3(3), 136-152. http://www.akrabjuara.com/index.php/akrabjuara/article/view/253.

Hidayat, A. (2021). Pengaruh Kompetensi dan Motivasi Terhadap Kinerja Guru di Gugus II Kecamatan Jatiwaras Kabupaten Tasikmalaya. Jurnal Revolusi Indonesia, 2(1), 21-30. http://fenery.org/index.php/jri/article/view/63.

Hidayat, Y. (2020). Peningkatan Kinerja dan Motivasi Mengajar terhadap Kompetensi Profesional Guru. Jurnal Pendidikan Pembelajaran Pemberdayaan Masyarakat, II(1), 121-130. https://doi.org/10.37577/jp3m.v2i1.199.

Janah, R., Akbar, Z., \& Yetti, E. (2020). Pengaruh Iklim Organisasi terhadap Kinerja Guru PAUD di Kota Depok. Jurnal Obsesi : Jurnal Pendidikan Anak Usia Dini, 4(1), 224-229. 
https://doi.org/10.31004/obsesi.v4i1.236.

Kartini, D., \& Kristiawan, M. (2019). Pengaruh Tunjangan Profesi dan Motivasi Kerja Terhadap Kinerja Guru. Kelola: Jurnal Manajemen Pendidikan, 6(1), 25-33. https://doi.org/10.24246/j.jk.2019.v6.i1.p25-33.

Kartini, D., Kristiawan, M., \& Fitria, H. (2020). The Influence of Principal's Leadership, Academic Supervision, and Professional Competence toward Teachers' Performance. International Journal of Progressive Sciences and Technologies (IJPSAT), 20(1), 156-164. https://doi.org/10.52155/ijpsat.v20.1.1730.

Kristiawan, M., \& Rahmat, N. (2018). Peningkatan Profesionalisme Guru Melalui Inovasi Pembelajaran. Jurnal Iqra': Kajian Ilmu Pendidikan, 3(2), 373-390. https://doi.org/10.25217/ji.v3i2.348.

Lalupanda, E. M. (2019). Implementasi Supervisi Akademik untuk Meningkatkan Mutu Guru. Jurnal Akuntabilitas Manajemen Pendidikan, 7(1), 62-67. https://doi.org/10.21831/amp.v7i1.22276.

Lie, D., Sherly, Dharma, E., \& Sudirman, A. (2019). The Impact of Work Discipline and Work Ethic on the Teacher Performance of Sultan Agung Pematangsiantar Private Middle School Teachers T.A. 2018/2019. International Journal of Business Studies, 3(3), 125-135. https://doi.org/10.32924/ijbs.v3i3.83.

Mahfud, M. (2021). Pengaruh Kepemimpinan Kepala Sekolah , Motivasi Kerja, dan Displin terhadap Kinerja Guru SMA Negeri Se-Kota Bima. Jurnal Manajemen Pendidikan Dan Ilmu Sosial, 2(1), 1-17. https://doi.org/10.38035/jmpis.v2i1.

Mulang, H. (2021). The Effect of Competences, Work Motivation, Learning Environment on Human Resource Performance. Golden Ratio of Human Resource Management, 1(2), 84-93. https://doi.org/10.52970/grhrm.v1i2.52.

Mundia Sari, K., \& Setiawan, H. (2020). Kompetensi Pedagogik Guru dalam Melaksanakan Penilaian Pembelajaran Anak Usia Dini. Jurnal Obsesi : Jurnal Pendidikan Anak Usia Dini, 4(2), 900-912. https://doi.org/10.31004/obsesi.v4i2.478.

Murkatik, K., Harapan, E., \& Wardiah, D. (2020). The Influence of Professional and Pedagogic Competence on Teacher's Performance. Journal of Social Work and Science Education, 1(1), 58-69. https://doi.org/10.52690/jswse.v1i1.10.

Normianti, H., Aslamiah, \& Suhaimi. (2019). Relationship of Transformational Leaders of Principal, Teacher Motivation, Teacher Organization Commitments with Performance of Primary School Teachers in Labuan Amas Selatan, Indonesia. European Journal of Education Studies, 5(2), 123-141. https://doi.org/10.46827/ejes.v0i0.2308.

Nurdin. (2017). Pengaruh Motivasi Mengajar dan Persepsi atas Lingkungan Sekolah terhadap Kinerja Guru. Pengaruh Motivasi Mengajar Dan Persepsi Atas Lingkungan Sekolah Terhadap Kinerja Guru, 2(1), 3342. https://doi.org/10.2121/mp.v2i1.792.g755.

Pianda, D. (2018). Kinerja Guru. CV Jejak.

Pratiwi, W. A., Prasetyo, I., \& Shabrina, M. N. (2021). Faktor-Faktor yang Berpengaruh terhadap Kinerja Guru Taman Kanak-Kanak. Jurnal Obsesi: Jurnal Pendidikan Anak Usia Dini, 5(2), 1741-1753. https://doi.org/10.31004/obsesi.v5i2.970.

Purwoko, S. (2018). Pengaruh Kepemimpinan Kepala Sekolah, Komitmen Guru, Disiplin Kerja Guru, dan Budaya Sekolah terhadap Kinerja Guru SMK. Jurnal Akuntabilitas Manajemen Pendidikan, 6(2), 149162. https://doi.org/10.21831/amp.v6i2.8467.

Putri, N. A., Seri, H., \& Sakdiahwati. (2019). Pengaruh Disiplin, Kompetensi Kepribadian Dan Supervisi Kepala Sekolah Terhadap Kinerja Guru Smp Negeri Di Palembang. Jurnal Ilmu Manajemen, 8(2), 2536. https://doi.org/10.32502/jimn.v8i2.1822.

Rahmayanti, Haryati, T., \& Noor, M. (2021). Impact of Professional Competence, Motivation and Work Discipline on Teacher Performance. Economic Education Analysis Journal, 10(2), 229-239. https://doi.org/10.15294/eeaj.v10i2.46181.

Rasam, F., Sari, A. I. C., \& Karlina, E. (2019). Peran Kompetensi dalam Meningkatkan Kinerja Guru di SMA Jakarta Selatan. Research and Development Journal of Education, 6(1), 41-52. https://doi.org/10.30998/rdje.v6i1.4371.

Roqib, M., \& Nurfuadi. (2020). Kepribadian Guru Upaya Mengembangkan Kepribadian Guru yang Sehat di Masa Depan. CV Cinta Buku.

Royani, I., Fitria, H., \& Rohana. (2020). Pengaruh Kepemimpinan Kepala PAUD dan Kompetensi Guru terhadap Kinerja Guru. Journal of Innovation in Teaching and Instructional Media, 1(1), 36-45. https://doi.org/10.52690/jitim.v1i1.28.

Septiani, V., \& Cahyono, D. (2019). Education and training strategy in Palembang aviation college. International Journal of Recent Technology and Engineering, 8(3), 7891-7894. https://doi.org/10.35940/ijrte.C6561.098319.

Setiawan, H. (2020). Pengaruh Kemampuan Manajerial Kepala Sekolah dan Motivasi Mengajar Terhadap 
Mutu Lulusan di SMA/SMK Sekecamatan Gunung Pelindung Lampung Timur. Jurnal Lentera Pendidikan Pusat Penelitian LPPM UM METRO, 5(1), 75-95. https://ojs.ummetro.ac.id/index.php/lentera/article/view/1344/904.

Sofia, A., \& Yulistia, A. (2020). Pengaruh Kompetensi Kepribadian terhadap Motivasi Kerja Guru Pendidikan Anak Usia Dini. PAUD Lectura: Jurnal Pendidikan Anak Usia Dini, 3(2), 12-18. https://doi.org/10.31849/paud-lectura.v3i02.3445.

Sopandi, A. (2019). Pengaruh Kompetensi Profesional Dan Kompetensi Kepribadian Terhadap Kinerja Guru. Scientific Journal of Reflection, 2(2), 121-130. https://doi.org/10.5281/zenodo.2628070.

Suharsaputra. (2018). Supervisi Pendidikan. PT Refika Aditama.

Sulfemi, W. B. (2020). Hubungan Sarana Prasarana Sekolah dengan Motivasi Mengajar Guru di SMA Negeri Pamijahan Kabupaten Bogor. Jurnal Ilmiah Edutecno, 22(1), 1-19. https://doi.org/10.35542/osf.io/p2fae.

Surani, D., \& Mifthahudin, M. (2018). Kompetensi Guru Dan Motivasi Mengajar Guru Berpengaruh Terhadap Efektivitas Pembelajaran Di Smk Negeri 3 Kota Serang. Tarbawi: Jurnal Keilmuan Manajemen Pendidikan, 4(2), 149-158. https://doi.org/10.32678/tarbawi.v4i02.1227.

Tanu, I. K. (2017). Pentingnya Pendidikan Anak Usia Dini Agar Dapat Tumbuh Dan Berkembang Sebagai Generasi Bangsa Harapan Di Masa Depan. Adi Widya: Jurnal Pendidikan Dasar, 2(2), 1-29. https://doi.org/10.25078/aw.v2i2.960.

Uno, H. B. (2017). Teori Motivasi dan Pengukurannya Analisis Bidang Pendidikan. PT Bumi Aksara.

Yunanda, I. (2019). Pengaruh Kompetensi dan Motivasi Mengajar terhadap Kinerja Guru (Studi pada Tazkia International Islamic Boarding School Malang). Jurnal Ilmiah Mahasiswa FEB, 1-18. https://jimfeb.ub.ac.id/index.php/jimfeb/article/view/5958/5243.

Zola, N., \& Mudjiran, M. (2020). Analisis Urgensi Kompetensi Kepribadian Guru. Jurnal EDUCATIO: Jurnal Pendidikan Indonesia, 6(2), 88-93. https://doi.org/10.29210/120202701. 